\title{
THE CURRENT CONDITIONS OF CSR IMPLEMENTATION IN CONSTRUCTION INDUSTRY: A LESSON FROM TAIWAN
}

\author{
HuANG, C. F. ${ }^{*}-$ LU, W. H. - LIN, T. T. - WU, E. J. \\ Department of Civil Engineering, National Kaohsiung University of Applied Sciences \\ Kaohsiung, Taiwan 80778 \\ (tel: +886-7-381-4526-5234; fax: +886-7-383-1371) \\ *Corresponding author \\ e-mail: jeffrey@kuas.edu.tw \\ (Received 12 $2^{\text {th }}$ Aug 2016; accepted $15^{\text {th }}$ Nov 2016)
}

\begin{abstract}
Nowadays, a growing number of companies are starting their corporate social responsibility (CSR) implementation and consider CSR as a kind of business strategy. To understand the current CSR implementation levels in construction industry and identify relatively easy-to-achieve CSR targets for companies interested in CSR, this study is conducted by analyzing the CSR reports of some large-sized companies in Taiwan's construction industry and by conducting a questionnaire survey on large-sized and reputable companies in construction industry to find out the CSR implementation levels of these construction companies and the differences between contractors and real-estate developers in their implementation measures. It found that even if a company in construction industry is interested in CSR implementation or CSR report issuance, it is driven by purposes such as business transformation or investment attraction. Moreover, different types of companies in construction industry have different focus in their CSR implementation dimensions. The contractors focus more on their environmental influence, carbon emissions and impact on biodiversity at their construction sites while the real-estate developers focus more on the pre-construction environmental evaluations of the construction sites and green building designs.
\end{abstract}

Keywords: corporate social responsibility; contractors; real-estate developers; CSR report; GRI

\section{Introduction}

In earlier days with less developed information circulation, the construction industry paid little attention to CSR, considering it as merely giving back to society without obtaining any gain in return. Because of the current economic slowdown, large-sized companies in Taiwan's construction industry are not as profitable as before. To ensure more stable profitability and growth, they have gradually started with different new business strategies: growing in size, internationalization. Some of them also have started to regard CSR as a kind of business strategy. CSR is often considered as one of the sources of competitive advantage. In a highly competitive, chaotic and ever-changing environment, socially responsible business behaviors are an effective and necessary strategy to ensure survival and sustainability (Frederick, 1998; Loosemore and Phua, 2011).

Eun et al. (2011) indicate that CSR is an increasingly important topic for academia and also a priority for companies. For development practitioners, CSR has become a major point of interest (Jenkins, 2005). According to Porter and Kramer's (2006), CSR is definitely worthy of consideration. Lichtenstein et al. (2004) contend that CSR can be a feasible promotional strategy to bring broader benefits for the company beyond immediate purchase behaviors. CSR can bring corporate profits and responsible social development (Berkhout, 2005). CSR reflects a growing public demand for greater transparency and accountability of companies. It can be used as a strategy to tackle 
externalities and serve as insurance against reputation risks that may damage profitability and corporate values (Ogrizek, 2002). As indicated by Piercy and Lane (2009), the influence of CSR initiatives on customers and other stakeholders is key to better performance. According to the suggestions by Yadong (2007), CSR should include: (1) external dimensions regarding relationships with suppliers and commitments to local community protection and engagement; (2) internal dimensions regarding relationships with employees and unions; and (3) transparency and accountability, including commitments to issuing CSR reports.

The construction process, from planning and design to use and demolition, has a significant influence on society (Fewings, 2009; Murray and Dainty, 2009). In general, the ethical reputation of the construction industry (Huang, 2014) has been quite poor, widely deemed by the public as a sector rife with problems such as corruption, health and safety hazards, and environmental pollution (Moodley et al., 2008). According to Petrovic-Lazarevic (2008), in the Australian construction industry, large companies have implemented CSR in order to be seen as good corporate citizens. Liu et al. (2011) point out that the Department of Trade and Industry in the UK is promoting CSR as a business contribution to sustainable development. Didier and Huet (2008) indicate CSR-related issues are discussed in higher education engineering courses in France but have not been implemented within the engineering-related industries in France. Common Wealth Magazine, a prestigious business magazine in Taiwan, started in 2000 its annual evaluations and rankings of companies' CSR realization in Taiwan. Amidst its "Top 50 Corporate Citizens" from 2012 to 2015, only one company is from the construction industry. Considering the social, economic and environmental impact of construction activities, the construction industry has more reasons to focus on CSR than most others (Murray and Dainty, 2009; Huang and Lien, 2012). Known as the "locomotive of industries," the construction industry is still lagging much behind the service, manufacturing and other industries, in terms of the awareness and implementation of CSR.

From the CSR reports of reputable construction companies, knowledge about the current levels of CSR implementation in the construction industry can be obtained. Among the CSR report writing standards, the global reporting initiative (GRI) is the most widely used. It provides comprehensive guidelines of corporate information disclosure and adopts the mechanism of external auditing, giving trustworthy credibility and transparency to CSR reports based on this standard. Because of its characteristics, the construction industry has more direct impact on the environment than the other industries. Environmental protection is an essential part of CSR. As issues of environmental protection are receiving increasing attention around the world, how to improve CSR implementation has become a priority for large-sized companies in Taiwan's construction industry in their strategic development. Better CSR implementation means not only healthy interactions between the government and the company but also stronger confidence in the company from investors and consumers.

In this study, the CSR reports of selected large-sized companies in Taiwan's construction industry are collected and analyzed to learn about the current conditions of CSR implementation in the industry. A questionnaire survey is also conducted to further explore the trends and problems of CSR implementation among companies in Taiwan's construction industry. To help promote CSR in construction industry, this study is intended to achieve the following purposes: 
1. To explore and analyze the current CSR implementation conditions of major construction companies, consisting of both contractors and real-estate developers in this study, in Taiwan through their CSR reports and a questionnaire survey; and

2. To find relatively easy-to-achieve CSR targets for companies in construction industry interesting in starting their CSR initiatives.

\section{Literature Review and Research Design}

\section{CSR Standards}

The concept of CSR refers to the responsibilities of a company for its ethical integrity, shareholder interests, labor rights, supplier management, consumer rights, environment, community participation, performance information disclosure, and stakeholders. Nowadays, companies are evaluated mainly based on their business performance not CSR performance. Companies with good CSR records are not necessarily companies with good business performance or profitability. Some regards CSR as companies' returning a portion of what they have gained from society back to society. In other words, in addition to the rights society has endowed upon them, companies have their obligations to society and they have to fulfill their obligations in ways acceptable to society. The International Standardization Organization (ISO) has also established a work group responsible for developing a set of CSR guidelines (ISO26000) and it is believed that ISO26000 will be applied not just to companies.

Among the CSR definitions proposed by many international organizations, experts and entrepreneurs, the following three major elements can be found:

1. Volunteerism as proposed by Steiner (1971): "More power comes with more responsibility" and so is with CSR. The larger a company becomes, the more social responsibilities it will shoulder. Walton (1967) believes that CSR includes self-discipline and spontaneity. One of the indispensable elements of CSR is the transition from obligation to volunteerism.

2. Consideration of lowering negative impact based on morality, laws and economic concerns: When pursuing economic interests, companies are also shouldering legal, social and economic responsibilities. Hopfenbeck (1992) believes that, in addition to the priority of fulfilling legal responsibilities and social responsibilities, companies must also voluntarily fulfill their moral responsibilities to lower the stress and moral impact of corporate responsibilities.

3. Meeting social expectation as indicated by Davis (1960): A company has a certain level of social influence. Therefore, in the process of its decision making, its economic benefits should not be the only concern (Davis and Blomstrom, 1975). A company must protect and promote social well-being and meet society's expectation of it.

The publication of CSR reports has been regarded as an indicator of CSR commitment and implementation for companies around the world. In some countries, CSR report compilation and production has become mandatory other than voluntary. According to a KPMG survey on Top 250 companies around the world in 2008, 79\% of these companies were implementing CSR, showing a 27\% increase from 2005. There are totally eight major CSR standards that are relatively well-recognized around the world (see Table 1.). They are called the "Global Eight" (McIntosh et al., 2003). 
Table 1. Eight Major International CSR Standards

\begin{tabular}{l}
\hline 1. The OECD Guidelines for Multinational Enterprises \\
\hline 2. The UN Global Compact \\
\hline 3. The Global Sulivan Principles \\
\hline 4. The Global Reporting Initiative (GRI) \\
\hline 5. International Labor Organization, ILO \\
\hline 6. Social Accountability 8000 (SA 8000) \\
\hline 7. Account Ability 1000 (AA 1000) \\
8. ISO 14000
\end{tabular}

According to Roca and Searcy (2012), GRI has received more recognition than the other seven for it is currently the most widely applied. Marimon et al. (2012) indicate that GRI is applied in approximately $40 \%$ of the CSR reports around the world.

\section{Current Development of CSR}

As the connections between companies and society grow closer, there are more internal and external factors influencing companies' participation in public welfare activities. To ensure the most effective use of resources, companies often have evaluation standards on their inputs in public welfare activities. Therefore, Ballou et al. (2006) believe that CSR reports are not just intended for the interests of shareholders but for the broader interests of stakeholders.

Maher (1984) compares the amounts of pretax earnings and public welfare activity sponsorship expenses of selected companies in the US from 1972 to 1982 and finds that, despite the trend of decreasing earnings, these companies were investing more in public welfare sponsorship. Therefore, he argues that corporate sponsorship of public welfare activities is obviously no longer an act of kindness but a means of marketing. Grahn et al. (1987) further explores "the relevance of marketing purposes" to illustrate that corporate engagement in public welfare activities is intended for non-marketing purposes (such as tax reduction or social responsibility fulfillment), marketing purposes (better corporate image and visibility) or a combination of both.

The Business Council for Sustainable Development of Taiwan (BCSD-Taiwan, ROC) was established in May 1997. Composed of over 30 large companies and organizations in Taiwan as it members, it is a branch of the WBCSD. It is dedicated to promoting sustainable development of companies in Taiwan through research programs, seminars, publications, and international exchanges on issues such as international trends of related regulations and policies, environmental management, education and training, resource preservation, ecological conservation, pollution prevention and ecological benefits ( $\mathrm{Li}, 2010)$.

\section{CSR Research}

Petrovic-Lazarevic (2008) indicates that construction companies worldwide are thinking about having their CSR initiatives with a view to enhancing their competitive advantages through better corporate images. They have gradually published reports on their charity donations and their activities of reducing pollutants, wastes, carbon emissions and energy consumption. According to Sierra et al. (2012), Spain is an international leader in terms of CSR reports. 
Hernandez (2015) argues that, among contractors, developers and suppliers, contractors have the best performance in sustainable operation and development. As defined by Perrini et al. (2003), corporate sustainability refers to the ability of a company to sustain its operation for a very long period of time and this ability depends on good relationships between the company and its stakeholders. Zhao et al. (2009) indicates all the CSR guidelines and standards developed by international organizations or experts fail to include stakeholders of the company. According to Carnevale et al. (2011) and Bonsón and Bednárová (2014), there is no significant connection found between CSR disclosure levels and the company's business performance. According to existing literature, there are significant differences in the CSR disclosure indicators and disclosure levels among different industries. Waddock (2008) believe that a nation's power can have an influence on the sustainable development report levels of companies in that nation.

\section{Research Framework and Method}

This research is composed of two stages. In the first stage, secondary data from CSR reports of nine construction companies listed in the stock market and OTC market in Taiwan were collected and compared. In the second stage, an expert questionnaire survey was conducted to learn the experts' opinions about CSR and CSR implementation levels of their companies. The questionnaire survey was mainly intended to explore and compare the CSR implementation levels of selected large-sized companies in Taiwan's construction industry in terms of four dimensions: (1) corporate governance; (2) labor rights; (3) environment; and (4) social engagement. Considering the characteristics of the construction industry in Taiwan, the experts had to be working in companies each with (1) 10 or more years of operation and certain level of reputation in the industry; (2) 100 or more employees (in the case of contractors) and 50 or more employees (in the case of real-estate developers); and (3) NT\$ 1 billion or more of turnovers in at least one of the past three years. There were totally 150 companies that met these requirements. One questionnaire was sent to a manager or someone at a higher position at each of the 150 companies. In the end, totally 60 questionnaires were collected. The questionnaire results were compiled and analyzed to develop further understanding about the core issues of CSR development in each of the dimensions currently in Taiwan's construction industry. In addition, the questionnaire results were compared with the contents in the CSR reports collected in the study.

\section{Research Results}

\section{Comparison of CSR Report Contents}

There are totally 69 companies in Taiwan's construction industry who are listed on the stock or OTC market. Among them, $51(74 \%)$ are real-estate developers, eight are contractors (12\%) and ten (14\%) are construction material companies. There are nine of these 69 companies $(13 \%)$ that have been issuing CSR reports. Six of them are contractors and the other three are real-estate developers. The company profile information of these nine companies (named respectively Company A, B, C, D, E, F, G, $\mathrm{H}$ and I) is listed and compared in Table 2. The following section is the comparison of their CSR report contents in each dimension referring to Table 3. 


\section{(1) Corporate Governance}

In their CSR reports, most of the nine companies have included contents about their CSR committees, risk management committees and stakeholders. All of them have established their CSR committees except Company C and F. Company E has CSR analysis on their governance/management, environment protection and social engagement. Company D uses the technology of BIM (Building Information Modeling) to analyze their performance in environment protection and energy conservation.

Table 2. Company Profile Information of the Nine Research Cases

\begin{tabular}{c|c|c|c|c|c}
\hline Item & Type & Established in & $\begin{array}{c}\text { Employee } \\
\text { Number }\end{array}$ & $\begin{array}{c}\text { Registered } \\
\text { Capital } \\
\text { (NT\$ 100 } \\
\text { million) }\end{array}$ & $\begin{array}{c}\text { Listed in } \\
\text { Stock Market }\end{array}$ \\
\hline A & Contractor & 1979 & 3,200 & 70 & Yes \\
\hline B & Contractor & 1983 & 450 & 4.5 & No \\
\hline C & Contractor & 1979 & 300 & 7.2 & No (only OTC) \\
\hline D & Contractor & 1982 & 408 & 10.6 & Yes \\
\hline F & Contractor & 1941 & 300 & 34.7 & Yes \\
\hline G & Contractor & 1950 & 800 & 152 & Yes \\
\hline H & $\begin{array}{c}\text { Real-estate } \\
\text { Developer }\end{array}$ & 1964 & 130 & 165 & Yes \\
\hline I & $\begin{array}{c}\text { Real-estate } \\
\text { Developer }\end{array}$ & 1973 & 300 & 105 & Yes \\
\hline
\end{tabular}

Table 3. Comparison of Corporate Governance Dimension

\begin{tabular}{l|c|c|c|c|c|c|c|c|c|c}
\hline \multicolumn{1}{c|}{ Item } & A & B & C & D & E & F & G & H & I & Total \\
\hline Establishment of CSR Committee & V & V & & V & V & & V & V & V & 7 \\
\hline Establishment of Risk Management Committee & V & V & V & V & V & & V & V & V & 8 \\
\hline Sustainable Operation and Development & V & V & V & V & V & V & V & V & V & 9 \\
\hline Stakeholder Analysis & V & V & V & V & V & V & V & V & V & 9 \\
\hline
\end{tabular}

\section{(2) Labor Rights}

As indicated in Table 4, all the nine companies provide their employees basic labor rights, welfare systems and safe working environments. In particular, Company A offers both employee club activities to bring employees closer together and good communication channels to learn more about employees' opinions. Company B employs diverse talent recruitment channels, such as industry-academia partnerships, talent recommendations by employees, job fairs on campus and online headhunting. It also has regular evaluations of its vendors. In terms of training and talent recruitment, Company B only has description in its CSR report about its training of labor health and safety without mentioning how it improves the overall professional skills of its employees. Company $\mathrm{C}$ is the only company that employs local people and vendors, helping to promote local development. In addition, it provides employees with opportunities of training and further education based on analyses of their conditions and requirements. It also has communication channels for its employees to express their opinions or complaints. Company E keeps records of the physical and psychological 
health conditions of its employees, gives them comprehensive training and supports employee club activities helpful for their physical and mental health. Company D pays great attention to its employees' behaviors and professional ethics, provides them diverse training and development programs, holds regular educational programs of vocational safety and health management to better ensure their safety, and provides direct and open communication channels for them.

Table 4. Comparison of Labor Rights Dimension

\begin{tabular}{l|c|c|c|c|c|c|c|c|c|c}
\hline \multicolumn{1}{c|}{ Item } & A & B & C & D & E & F & G & H & I & Total \\
\hline Basic Rights & V & V & V & V & V & V & V & V & V & 9 \\
\hline Welfare System & V & V & V & V & V & V & V & V & V & 9 \\
\hline Safe Working Environment & V & V & V & V & V & V & V & V & V & 9 \\
\hline Good Communication Channels & V & & V & V & & & V & V & V & 6 \\
\hline $\begin{array}{l}\text { Care for Employees' Physical and } \\
\text { Psychological Conditions }\end{array}$ & & & & V & V & & V & & V & 4 \\
\hline Training and Education & V & V & V & V & V & V & V & V & V & 9 \\
\hline $\begin{array}{l}\text { Providing Overseas Training } \\
\text { Opportunities }\end{array}$ & & & V & & & & V & & & 2 \\
\hline Employee Club Activities & V & & & & V & & & & & 2 \\
\hline Employment of local people & & & V & & & & & & & 1 \\
\hline
\end{tabular}

\section{(3) Environment}

As indicated in Table 5, all the nine companies seek sustainable operation through measures of energy conservation. In particular, Company A keeps daily records of its energy consumption volume, carbon emission volume and resource consumption volume. It also holds environment protection contests among its construction sites. Company B promotes natural resource conservation and adopts the 6S Policy, an innovative environment and health policy, which covers seiri (organization), seiton (neatness), seiso (cleaning), seiketsu (standardization), shitsuke (discipline and training) and safety. Company $\mathrm{C}$ applies measures such as green environment, green sourcing, environmental protection expenditure, waste reduction and pollution prevention to protect the environment. Company E uses site-specific measures to protect the environment of its construction sites. Company D conducts biodiversity surveys to protect the fauna and flora nearby its construction sites.

Table 5. Environment Dimension Comparison

\begin{tabular}{l|c|c|c|c|c|c|c|c|c|c}
\hline \multicolumn{1}{c|}{ Item } & A & B & C & D & E & F & G & H & I & Total \\
\hline Energy Conservation & V & V & V & V & V & & V & V & V & 8 \\
\hline $\begin{array}{l}\text { Greenhouse Gas Emission } \\
\text { Reduction }\end{array}$ & V & V & V & V & V & & V & V & V & 8 \\
$\begin{array}{l}\text { Use of Renewable Materials and/or } \\
\text { Energies }\end{array}$ & $\mathrm{V}$ & & & & & & V & V & & 3 \\
\hline $\begin{array}{l}\text { Protection of Local Environment, } \\
\text { Flora and Fauna }\end{array}$ & V & V & V & V & V & & V & V & & 7 \\
\hline Waste Treatment & V & V & V & V & V & V & V & V & V & 9 \\
\hline Water Pollution Prevention & V & V & V & V & V & & V & V & V & 8 \\
\hline Noise Prevention & V & & & V & V & & V & V & & 5 \\
\hline Air Pollution Prevention & V & V & V & V & V & & V & V & V & 8 \\
\hline
\end{tabular}




\section{(4) Social Engagement}

As indicated in Table 6, eight of the nine companies implement their social engagement through public welfare activities. Companies A, B and $\mathrm{E}$ also make their contributions to society by offering their professional opinions pro bono for disaster rescue work and providing evaluations of architectural structure damage for buildings in the disaster area to help ensure the security and safety of the affected residents. Companies B, C and D also forged partnerships with schools, provide opportunities for graduates-to-be to learn how to adapt to their future working environments and also reducing future personnel training costs.

Table 6. Comparison of the Social Engagement Dimension

\begin{tabular}{|c|c|c|c|c|c|c|c|c|c|c|}
\hline Item & A & B & C & D & $\mathbf{E}$ & $\mathbf{F}$ & G & $\mathbf{H}$ & I & Total \\
\hline Public Welfare Activities & $\mathrm{V}$ & $\mathrm{V}$ & $\mathrm{V}$ & $\mathrm{V}$ & $\mathrm{V}$ & & $\mathrm{V}$ & $\mathrm{V}$ & $\mathrm{V}$ & 8 \\
\hline Pro Bono Repair & & $\mathrm{V}$ & & & & & & & $\mathrm{V}$ & 2 \\
\hline $\begin{array}{l}\text { Disaster Rescue and Architectural } \\
\text { Structural Evaluation }\end{array}$ & V & V & & & $\mathrm{V}$ & & & & $\mathrm{V}$ & 4 \\
\hline Participation in Public Projects & & & $\mathrm{V}$ & & $\mathrm{V}$ & $\mathrm{V}$ & & & & 3 \\
\hline Industry-academia Partnerships & & $\mathrm{V}$ & $\mathrm{V}$ & $\mathrm{V}$ & & & $\mathrm{V}$ & $\mathrm{V}$ & & 5 \\
\hline Helping the Underprivileged & $\mathrm{V}$ & $\mathrm{V}$ & & $\mathrm{V}$ & $\mathrm{V}$ & & $\mathrm{V}$ & $\mathrm{V}$ & $\mathrm{V}$ & 7 \\
\hline Services for Local Communities & & & $\mathrm{V}$ & $\mathrm{V}$ & & & $\mathrm{V}$ & $\mathrm{V}$ & $\mathrm{V}$ & 5 \\
\hline Customer Satisfaction Survey & $\mathrm{V}$ & $\mathrm{V}$ & & $\mathrm{V}$ & & & $\mathrm{V}$ & $\mathrm{V}$ & $\mathrm{V}$ & 6 \\
\hline
\end{tabular}

\section{(5) Differences between Contractors and Real-estate Developers in CSR Implementation Dimensions}

In the corporate governance dimension, the nine construction companies have comprehensive information disclosure of their internal management guidelines, systems, company conditions and governance. In the labor rights dimension, they all provide basic labor rights, employee welfare systems, education and training activities, and safe working environments. However, for the contractors, their employees mostly engage in construction activities. Therefore, they focus more on equipping their employees with knowledge about labor safety and health protection than the real-estate developers.

In the environment dimension, both the contractors and the real-estate developers focus on sustainable operation. The contractors have a direct impact on the environment and ecosystem at their construction sites. To meet the expectations of environmental protection from society, they have more comprehensive information disclosure about their greenhouse gas emission reduction and monitoring. By contrast, the real-estate developers focus more on planning and design in their business. Therefore, they have more information disclosure about use of recycled and/or environmental friendly materials, evaluations of the environment, fauna and flora at the construction sites before construction, and green/smart buildings.

In the social engagement dimension, the contractors and the real-estate developers mainly focus on public welfare/charity activities and helping the underprivileged. In particular, some of the contractors provide pro bono evaluations of building structures after disasters and assist with disaster rescue work by providing their professional knowledge and technology. This kind of social engagement can help to improve their corporate images. The real-estate developers mainly improve their images and make their contributions to society through educational/cultural activities and local community services. 


\section{Analysis of CSR Implementation Levels in Taiwan's Construction Industry}

Table 7 lists the corporate profile information of the subjects in the questionnaire survey of this study. Among them, ten (16.7) have established their CSR committees, six $(10 \%)$ have planned their CSR committee establishment and are implementing their plans, ten $(16.7 \%)$ have planned their CSR committee establishment but are not implementing their plans. Among these companies, 34 (56.7\%) have not established CSR committees yet and only nine $(22.5 \%)$ have plans to establish CSR committees. This finding reflects that most of the companies in the construction industry have not fully implemented CSR in Taiwan.

Table 7. Corporate Profile Information of the Questionnaire Survey Subjects

\begin{tabular}{|c|c|c|c|}
\hline Category & Item & Number & Ratio \\
\hline \multirow{2}{*}{ Company Type } & Contractor & 30 & $50.0 \%$ \\
\hline & Real-estate Developer & 30 & $50.0 \%$ \\
\hline \multirow{4}{*}{$\begin{array}{l}\text { Establishment of CSR } \\
\text { Committee }\end{array}$} & Yes & 10 & $16.7 \%$ \\
\hline & Planned and being implemented & 6 & $10.0 \%$ \\
\hline & Planned but not implemented & 10 & $16.7 \%$ \\
\hline & No Plan & 34 & $56.7 \%$ \\
\hline \multirow{4}{*}{$\begin{array}{l}\text { Registered Capital } \\
\text { (NT\$ billion) }\end{array}$} & $0.1 \sim<0.2$ & 12 & $20.0 \%$ \\
\hline & $0.2 \sim<1$ & 18 & $30.0 \%$ \\
\hline & $1 \sim<4$ & 18 & $30.0 \%$ \\
\hline & $>4$ & 12 & $20.0 \%$ \\
\hline \multirow{4}{*}{$\begin{array}{l}\text { Turnover Last Year } \\
\text { (NT\$ billion) }\end{array}$} & $1<3$ & 20 & $33.3 \%$ \\
\hline & $3 \sim<6$ & 13 & $21.7 \%$ \\
\hline & $6 \sim<10$ & 14 & $23.3 \%$ \\
\hline & $>10$ & 13 & $21.7 \%$ \\
\hline \multirow{4}{*}{ Number of Employees } & $50 \sim<100$ & 28 & $46.7 \%$ \\
\hline & $10 \sim<200$ & 9 & $15.0 \%$ \\
\hline & $201 \sim<400$ & 9 & $15.0 \%$ \\
\hline & $>400$ & 14 & $23.3 \%$ \\
\hline \multirow{4}{*}{ Company Age } & $10 \sim<20$ Years & 16 & $26.7 \%$ \\
\hline & $20 \sim<30$ Years & 17 & $28.3 \%$ \\
\hline & $30 \sim<40$ Years & 14 & $23.3 \%$ \\
\hline & $>40$ Years & 13 & $21.7 \%$ \\
\hline \multirow{4}{*}{ CSR Report Issuance } & Yes & 7 & $11.7 \%$ \\
\hline & No but Report under Production & 9 & $15.0 \%$ \\
\hline & No but Preparing & 9 & $15.0 \%$ \\
\hline & No Plan & 35 & $58.3 \%$ \\
\hline \multirow{2}{*}{$\begin{array}{c}\text { Listed on the Stock/OTC } \\
\text { Market }\end{array}$} & Yes & 24 & $40.0 \%$ \\
\hline & No & 36 & $60.0 \%$ \\
\hline \multirow{2}{*}{ Overseas Branch/Investment } & Yes & 19 & $31.7 \%$ \\
\hline & No & 41 & $68.3 \%$ \\
\hline \multirow{3}{*}{ Major Clients } & Governmental Organizations & 6 & $10.0 \%$ \\
\hline & Private Entities & 42 & $70.0 \%$ \\
\hline & Both & 12 & $20.0 \%$ \\
\hline
\end{tabular}

As indicated in Table 8, among those companies with over 200 employees, seven (30.7\%) have established their CSR committees, higher than the $8.1 \%$ among the companies with less than 200 employees. This finding indicates that, with more employees, a company will have more sufficient human resources and more willingness to establish its CSR committee. 
Table 8. Number of Employees and Establishment of CSR Committee

\begin{tabular}{|c|c|c|c|c|c|c|}
\hline & & \multicolumn{4}{|c|}{ CSR Committee Establishment } & \multirow[b]{2}{*}{ Total } \\
\hline & & Established & $\begin{array}{l}\text { Planned and } \\
\text { Implementing }\end{array}$ & $\begin{array}{c}\text { Planned but Not } \\
\text { Implemented }\end{array}$ & No Plan & \\
\hline \multirow{4}{*}{$\begin{array}{l}\text { Number of } \\
\text { Employees }\end{array}$} & \multirow{2}{*}{$<200$} & 3 & 4 & 6 & 24 & 37 \\
\hline & & $8.1 \%$ & $10.8 \%$ & $16.2 \%$ & $64.9 \%$ & $100.0 \%$ \\
\hline & \multirow{2}{*}{$>200$} & 7 & 2 & 4 & 10 & 23 \\
\hline & & $30.4 \%$ & $8.7 \%$ & $17.4 \%$ & $43.5 \%$ & $100.0 \%$ \\
\hline \multirow{2}{*}{\multicolumn{2}{|c|}{ Total }} & 10 & 6 & 10 & 34 & 60 \\
\hline & & $16.7 \%$ & $10.0 \%$ & $16.7 \%$ & $56.7 \%$ & $100.0 \%$ \\
\hline
\end{tabular}

According to Table 9, ten (20.4\%) of the companies with registered capital of over NT\$1 billion each have established their CSR committees. Among the eleven companies each with registered capital of less than NT\$1 billion, eight (72.7\%) have no plan of CSR committee establishment, compared with 26 companies $(53.1 \%)$ that have no plan of CSR establishment among the 49 companies each with registered capital of over NT\$1 billion. This finding reflects that larger companies with more registered capital have more resources for CSR committee establishment.

Table 9. Registered Capital and CSR Committee Establishment

\begin{tabular}{|c|c|c|c|c|c|c|}
\hline & & \multicolumn{4}{|c|}{ CSR Committee Establishment } & \multirow[b]{2}{*}{ Total } \\
\hline & & Established & $\begin{array}{c}\text { Planned and } \\
\text { Implementing }\end{array}$ & $\begin{array}{c}\text { Planned but not } \\
\text { Implemented }\end{array}$ & No Plan & \\
\hline \multirow{4}{*}{$\begin{array}{l}\text { Registered } \\
\text { Capital }\end{array}$} & \multirow{2}{*}{$\begin{array}{l}<\text { NT\$1 } \\
\text { Billion }\end{array}$} & 0 & 1 & 2 & 8 & 11 \\
\hline & & $0.0 \%$ & $9.1 \%$ & $18.2 \%$ & $72.7 \%$ & $100.0 \%$ \\
\hline & \multirow{2}{*}{$\begin{array}{l}\text { >NT\$1 } \\
\text { Billion }\end{array}$} & 10 & 5 & 8 & 26 & 49 \\
\hline & & $20.4 \%$ & $10.2 \%$ & $16.3 \%$ & $53.1 \%$ & $100.0 \%$ \\
\hline \multirow{2}{*}{\multicolumn{2}{|c|}{ Total }} & 10 & 6 & 10 & 34 & 60 \\
\hline & & $16.7 \%$ & $10.0 \%$ & $16.7 \%$ & $56.7 \%$ & $100.0 \%$ \\
\hline
\end{tabular}

As indicated in Table 10, the contractors and the real-estate developers in this study are not significantly different in their CSR implementation levels. Among the corporate samples in this study, five contractors and two real-estate developers issued CSR reports this year, compared with three real-estate developers and six contractors in 2015 and only two contractors in 2014. Even though this finding reflects a growing number of companies in the construction industry that have issued their CSR reports, the CSR report issuance in the construction industry is increasing slowly.

Table 10. Comparison of Contractors and Real-estate Developers in CSR Implementation Dimensions

\begin{tabular}{c|c|c|c|c|c}
\hline Dimension & Company Type & Average & Difference & t & Significance \\
\hline \multirow{2}{*}{$\begin{array}{c}\text { Corporate } \\
\text { Governance }\end{array}$} & Contractor & 4.44 & \multirow{2}{*}{0.08} & 0.30 & 0.78 \\
\cline { 2 - 3 } Labor Rights & $\begin{array}{c}\text { Real-estate } \\
\text { Developer }\end{array}$ & 4.36 & 0.26 & 1.09 & 0.28 \\
\cline { 2 - 4 } & $\begin{array}{c}\text { Contractor } \\
\text { Real-estate } \\
\text { Developer }\end{array}$ & 4.02 & 0.76 & 0.26 \\
\hline
\end{tabular}




\begin{tabular}{c|c|c|c|c|c}
\hline \multirow{3}{*}{ Environment } & Contractor & 4.59 & \multirow{2}{*}{-0.34} & -1.46 & 0.15 \\
\cline { 2 - 3 } & $\begin{array}{c}\text { Real-estate } \\
\text { Developer }\end{array}$ & 4.93 & -0.09 & -0.37 & 0.76 \\
\hline \multirow{3}{*}{ Social Engagement } & \begin{tabular}{l} 
Contractor \\
\cline { 2 - 3 }
\end{tabular} & $\begin{array}{c}\text { Real-estate } \\
\text { Developer }\end{array}$ & 4.41 & -50 & 0.09 \\
\hline
\end{tabular}

\section{Conclusion and Suggestion}

\section{CSR Implementation of Large-sized Companies in the Construction Industry}

The CSR reports of large-sized companies in Taiwan's construction industry contain relatively comprehensive information about their CSR implementation. By contrast, those companies that have not issued CSR reports only regard CSR as simply giving back to society and only implement CSR when they are making profits without much consideration about sustainable development. Among those companies in this research that are willing to establish or have established their CSR committees, 54.3\% are traded on the stock/OTC market, $72.7 \%$ are companies with a history of over 30 years each, $72 \%$ are companies with registered capital of over NT $\$ 1$ billion each, and $72 \%$ are companies with over 200 employees each. This finding indicates that larger companies in Taiwan's construction industry have higher willingness to establish CSR committees.

Except for the companies that have issued CSR reports, those companies interested in CSR implementation or even CSR report issuance are mainly driven by one or more of the following three reasons: (1) transformation into a company of bigger size and scale; (2) plan to be listed in the stock/OTC market; and (3) expanding overseas business.

In addition, according to the CSR report analysis results of this study, the contractors and the real-estate developers are not significantly in their CSR implementation levels. However, they are mainly different in the CSR dimensions they focus on. The contractors pay more attention to their environmental influence, carbon emissions and impact on biodiversity at their construction sites. By contrast, the real-estate developers focus more on the pre-construction environmental evaluations and energy-saving designs.

\section{Suggestions of CSR Targets for Companies}

Based on the CSR reports collected in this study and the questionnaire results analysis findings, easy-to-reach targets in each of the following four CSR dimensions are suggested as follows:

\section{(1) Corporate Governance}

CSR committee establishment: CSR implementation must start from the high-level leadership at the company. The establishment of a dedicated organization at the high-level will significantly help to promote all the CSR projects. This organization will help to ensure top-down CSR implementation to achieve maximum results.

\section{(2) Labor Rights (GRI G4-LA1 LA16)}

To provide employees with a good working environment, welfare system, education and training activities, good communication channels, and knowledge about labor safety 
and health. CSR implementation also requires efforts and collaboration from employees at the bottom; therefore, it is very important to give employees a safe, healthy and encouraging environment.

\section{(3) Environment (GRI G4-NE15 NE21, EN34)}

Real-estate developers are suggested to conduct pre-construction environmental evaluations of the construction sites, select environmentally friendly materials for architecture design, and/or design/build green buildings. Contractors are suggested to pay attention to their pollution and carbon emissions during the construction process and select construction techniques suitable for each construction site to reduce their impact on local environment.

\section{(4) Social Engagement (GRI G4-SO1 SO5)}

Strengthening connections with schools: It is found in this study that CSR implementation in Taiwan's construction industry is relatively weak in terms of connections with schools. Measures such as providing scholarships, internships or work-study opportunities and industry-academia partnerships are suggested to not only recruit future talent but also improve the corporate image.

Acknowledgements. We gratefully acknowledged the financial support (NSC 100-2221-E-151-050-) from Taiwan's Ministry of Science and Technology.

\section{REFERENCES}

[1] BCSD-Taiwan, ROC, http://www.bcsd.org.tw/info/event/data/1179, visit date: 2016/02/11.

[2] Berkhout, T., (2005): Corporate gains: corporate social responsibility can be the strategic engine for long-term corporate profits and responsible social development. Alternatives Journal 31(1): 15-18.

[3] Bonsón, E., Bednárová, M. (2014): CSR reporting practices of Eurozone companies. Spanish Accounting Review.

[4] Carnevale, C., Mazzuca, M., Venturini, S. (2011): Corporate Social Reporting in European Banks: The Effects on a Firm's Market Value. - Corporate Social Responsibility and Environmental Management 19(3): 159-177.

[5] Davis, K. (1960): Can Business Afford to Ignore Social Responsibilities? - California Management Review 2(3): 70-76.

[6] Davis, K., Blomstrom, R.L. (1975): Business and Society: Environment and Responsibility - Mcgran Hill, New York.

[7] Didier, C., Huet, R. (2008): Corporate social responsibility in engineering education: A French survey. - European Journal of Engineering Education 33(2): 169-177.

[8] Eun, M. L., Park, S. Y., Molly, I. R., Christopher, L. N. (2011): Does perceived consumer fit matter in corporate social responsibility issues? - Journal of Business Research, In Press, Available online 25 March.

[9] Fewings, P. (2009): Ethics for the Built Environment. Taylor \& Francis, London and New York.

[10] Frederick, W. C. (1998): Creatures, corporations, communities, chaos complexity. Business and society 37(12): 358-389.

[11] Grahn, J. L., Hannaford, W. J., Laverty, K. J. (1987): Corporate philanthropy and marketing strategy: A review and directions for research in AMA educators proceeding 
(Series53):67-69, Chicago.

[12] Hernandez H. A. L. (2015): Sustainable Performance and the Relationship between Indicators in CSR reports of Construction Companies - master's thesis, National Cheng Kung University, Tainan.

[13] Hopfenbeck, W. (1992): Management revolution: Lessons in Environmental Excellence Prentice Hall, Hemel Hempstead.

[14] Huang, C. F. (2014): The associations among civil engineer's ethical education experiences, ethical beliefs, ethical perceptions and ethical behaviors - International Journal of Engineering Education, 30(5): 1166-1175.

[15] Huang, C. F., Lien, H. C. (2012): An Empirical Analysis of the Influences of Corporate Social Responsibility on Organizational Performance of Taiwan's Construction Industry: Using Corporate Image as a Mediator - Construction Management and Economics, 30(4): 263-275.

[16] International Standardization Organization, http://www.iso.org/iso/home.html, visit date: 2016/05/03.

[17] Jenkins, R. (2005): Globalization, corporate social responsibility and poverty. International Affairs, 81(3): 525-540.

[18] Li, M. C. (2010): A Brief Analysis on CSR Development Trend - Gre Tai Securities Market, 141, Taipei.

[19] Lichtenstein, D. R., Drumwright, M. E., Braig, B. M. (2004): The effect of corporate social responsibility on customers' donation to corporate-supported non-profits. - Journal of Marketing, 68(4): 16-32.

[20] Liu, A., Fellows, R., Tuuli, M. M. (2011): The role of corporate citizenship values in promoting corporate social performance: towards a conceptual model and a research agenda. - Construction Management and Economics, 29, 173-183.

[21] Maher, P. (1984): What corporations get by giving. - Business Marketing 69(12): 80-89.

[22] Marimon, M. Alonso-Almeida, M. Rodríguez. (2012): The worldwide diffusion of the global reporting initiative: What is the point? - Journal of Cleaner Production, 33: 132-144.

[23] McIntosh, M., Thomas, R., Leipziger, D., Coleman, G. (2003): Living Corporate Citizenship-Strategic Routes to Socially Responsible Business - Financial Times Prentice Hall, London.

[24] Moodley, K., Smith, N., Christopher, N. P. (2008): Stakeholder matrix for ethical relationships in the construction industry. - Construction Management and Economics, 26(6), 625-632.

[25] Murray, M., Dainty, A. (2008): Corporate Social Responsibility in Construction Industry. Taylor \& Francis, Abingdon, England.

[26] Ogrizek, M. (2002): The effect of corporate social responsibility on the branding of financial services. - Journal of Financial Services Marketing, 6(3), 215-228.

[27] Perrini, F., Tencati, A. (2003): Corporate social responsibility and firm performance: managing sustainability and the need of a new corporate evaluation and reporting system in a knowledge economy. - In Academy of Management Conference. Seattle, WA.

[28] Petrovic-Lazarevic, S. (2008): The development of corporate social responsibility in the Australian construction industry. - Construction Management and Economics, 26: 93-101.

[29] Porter, M. E., Kramer, M. R. (2006): Strategy and society: the link between competitive advantage and corporate responsibility. - Harvard Business Review 84(12): 78-92.

[30] Roca, L. C., Searcy, C. (2012): An analysis of indicators disclosed in corporate sustainability reports. - Journal of Cleaner Production 20: 103-118.

[31] Sierra, A., Zorio, M.A., García-Benau. (2012): Sustainable development and assurance of corporate social responsibility reports published by Ibex-35 companies - Corporate Social Responsibility and Environmental Management. 
[32] Steiner, G. A. (1971): Business and Society. - Random House, New York.

[33] Taiwan Stock Exchange, http://cgc.twse.com.tw/front/responsibility, visit date: 2016/04/30

[34] Waddock, S. (2008): Building a new institutional infrastructure for corporate responsibility. - Academy of Management Perspectives 22(3):87-108.

[35] Walton, C. C. (1967): Corporate Social Responsibilities. - Belmont, CA: Wadsworth.

[36] Yadong, L. (2007): Global Activities of Corporate Governance. - Blackwell Publishing, Oxford.

[37] Zhao, Z. Y., Shen, L. Y., Zuo, J. (2009): Performance and strategy of Chinese contractors in the international market. - Journal of Construction Engineering and Management 35 (2): 108-118. 